\title{
Building Future Societies? A Brief Analysis of Braga's School Bus Project
}

\author{
Emília Araújo $^{1(\otimes)}\left(\mathbb{D}\right.$, Márcia Silva $^{1}$ (D), Rita Ribeiro ${ }^{1}$ (D), and Filipa Corais ${ }^{2}$ (D) \\ ${ }^{1}$ Communication and Society Research Centre, University of Minho, Braga, Portugal \\ emiliararaujo@gmail.com \\ 2 Municipality of Braga, Braga, Portugal
}

\begin{abstract}
This paper seeks to demonstrate the importance of implementing transport policies that meet home to school (and vice versa) mobility needs of children and young people. Over the last few years families' mobility has been given increasing attention. One of the most investigated aspects is home to work mobility. Nowadays there is an urgent need to study and propose intervention measures regarding children's mobility to school. In fact, studies show that the car is the preferred mode of transportation in Portugal. This trend has undoubtedly negative social, environmental and health consequences. Based on an evaluation study on the School Bus project in Braga (a research- intervention activity of BUILD-Braga Urban Innovation Laboratory Demonstrator), this paper discusses the difficulties in implementing sustainable mobility initiatives, pointing out anticipatory measures that can be taken in medium-sized cities in order to stop the expansion of children's transportation by car, and give them back spaces in the cities.
\end{abstract}

Keywords: Urban mobility $\cdot$ Future $\cdot$ City $\cdot$ Children $\cdot$ School bus $\cdot$ BUILD

\section{Introduction}

This paper aims to show the importance of implementing transport policies for children and young people that meet the needs of families and, at the same time, actively contribute to the much urgent change to more sustainable transport practices, particularly in cities with high population density and where circulation has become progressively chaotic due to the increase in vehicle circulation. It is based on the analysis of the available literature on school transport and the implementation of sustainable mobility for children and young people, and addresses the School Bus project, implemented in the city of Braga, in the North of Portugal.

There are several reasons for thinking about transportation of children and young people to school as a social and sociological problem. Among those reasons, the following ought to be stressed: (i) the regular and growing use of cars and the consequent rush-hour traffic chaos in the cities, which are the cause of accidents, and endless congestions, as well as considerable delays, which expose children and families to stress and anxiety; (ii) the weak provision of public transport and the non- adequacy of these to the mobility needs of families with school-age children and young people, as regards routes 
and schedules, among others; (iii) the distance between schools and the families' place of residence and their motivation to add their rides to work with the ones to school and; (iv) the low or total absence of participation of populations, schools, children and young people in the definition of transport policies aimed at quality of life and development of sustainable cities.

In this paper, we find it crucial that the transport of children and young people to and from school becomes a subject of collective and political concern, which involves rethinking and planning urban mobility holistically, not leaving decisions only up to families or schools. Accordingly, we propose the use of transdisciplinary approaches to children and young people's mobility, by suggesting there is a need to help practitioners develop innovation and entrepreneurial actions that are responsible and sustainable, in order to safeguard an alternative and better future for urban areas.

This paper is structured as follows. First, there is a brief introduction to the way social sciences, and particularly sociology, have been working on the phenomenon of children's mobility to and from school, considering that children's transport is a major issue in modern societies. Then, we describe the methodological steps developed during a research and evaluation project on the implementation of the school bus in the city of Braga. Afterwards we describe how families and children joined the school bus initiative and analyze its main positive and negative points. Finally, we discuss some practical considerations about the way children's mobility can be managed in order to reduce existing traffic congestion due to the massive use of cars in the city.

\section{Urban Mobility: From Difficulties to Opportunities}

Society's car dependency is difficult to revert [1-3] and entails several implications for children's lives [4]. In fact, children miss out on the opportunity to gain skills and autonomy, as well as the opportunity for social interactions, when circulating almost exclusively in cars. Furthermore, families waste time that could be used in more stimulating and fruitful activities. Besides health problems related to high levels of air pollution, and other diseases brought about by the increasing accelerated pace of life, cars are also related to the abovementioned increase in traffic congestion. It is a fact that the problem of traffic in cities, particularly in southern European countries, has been addressed by putting a great emphasis on the need to transition to electric and autonomous cars. However, this transition does not solve any major effects caused by cars. Instead, it only reshapes urban spaces' current challenges.

Actually, it is urgent to integrate school mobility and mobility of families in urban policies, by promoting means of movement and transport which, at the same time, empower children and allow them to enjoy public space and ensure a safe circulation between school, home and other places (for example, extracurricular activities) in a more sustainable way. This can be achieved in several ways, including by implementing the use of public transport, or by encouraging safe walking routes for children in their way to school. In any case, families and children needs must always be met. Most importantly, giving them back public space and teaching them how to reuse the time and space of transportation and travel, is a key factor for quality of life in the cities of the future. 


\subsection{The Problem of Mobility in Braga}

From the citizen's point of view, assessed through field observation, the circulation in Braga has been getting increasingly more difficult for these last couple of years. People complain about the fact that there is traffic everywhere, circulation is very slow and parking is scarce and expensive.

Braga has currently about 181,000 inhabitants, with $57.8 \%$ of the population aged between $25-64$, while the population under 25 is about $26 \%$. The city centre is where most of the services, such as schools, health care services, public services, sports centres, among others, are. Braga attracts many people every day (about 48.020 movements) mostly from neighbouring counties: Vila Verde (11.502), Guimarães (10.638) and Barcelos (9.415) [5]. About 27.285 people move from Braga every day. The use of cars in Braga has been growing since $2010(+17.5 \%)$. This is a trend that follows what is happening all over the country [6] (Fig. 1).

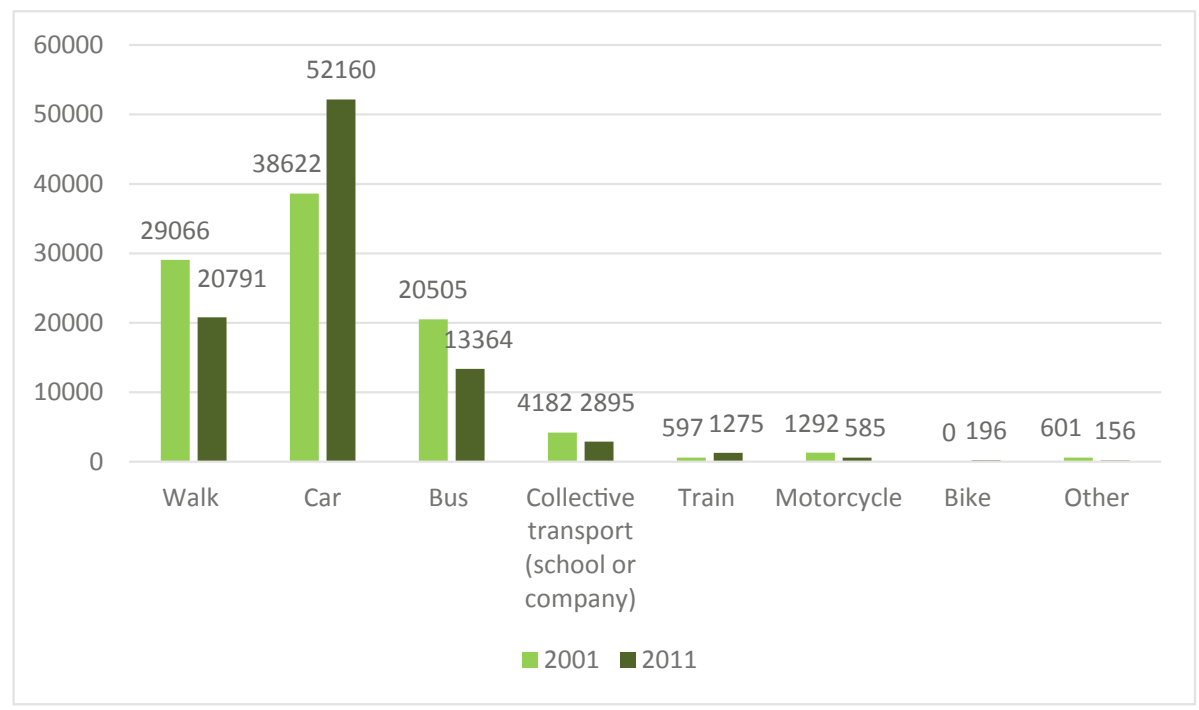

Fig. 1. Predominant means of transportation in Braga Source: $[7,8]$

According to Teles [5], cars are used in about $67.3 \%$ of the movements within the county, and $79.8 \%$ outside the county. The average time spent in commuting home to work or schools is about 15 min (58.6\%), with $30.5 \%$ of commuters spending 16 to $30 \mathrm{~min}$. Rush hours occur between 8 and $9 \mathrm{am}$, and between 6 and $7 \mathrm{pm}$. There are about 499 cars per 1000 inhabitants in Braga - a value equivalent to the national average. According to the same study [5], and because there are numerous schools in the city centre, car transportation to schools between 2001 and 2011 has grown more than 33\%. These numbers clearly confirm the massive use of cars in day-to-day journeys, including home-school movement, and corroborate citizens' perception about mobility in Braga being "chaotic", "slow", "difficult" and "dangerous" (Fig. 2). 


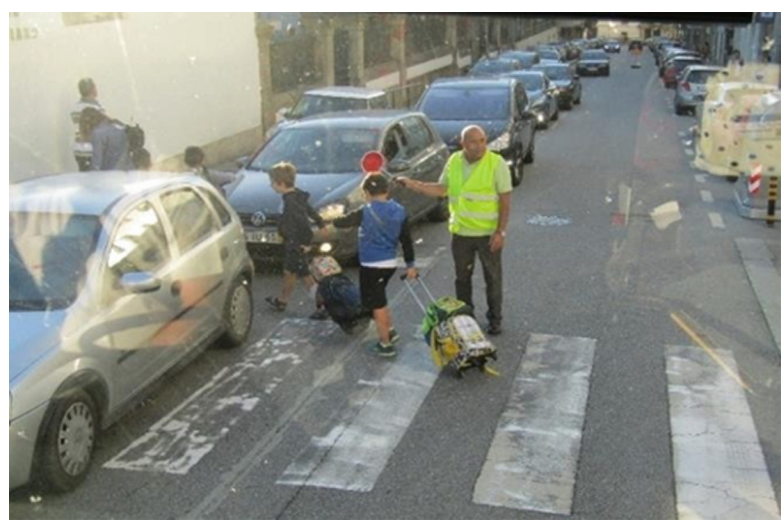

Fig. 2. Children crossing a street near school, in Braga (a car prevents them from crossing in the right place)

\section{School Buses as a Key Answer to Sustainable Mobility}

Nowadays, school buses are seen as an innovative, sustainable alternative in urban mobility. They are used worldwide for transporting students to and from school. Some of their most relevant effects relate to an increase in air quality by reducing $\mathrm{CO}_{2}$ and other pollutant emissions, a decrease in traffic flow to schools, an increase in children's safety in their way to school and time families spend together. Besides being in tune with current environmental concerns, the fact is that the School Bus goes back a long way.

The first School Bus dates back to 1827, when George Shillibeer, inspired by buses in Paris, took the initiative to London. Despite its Parisian origin, it was in the United States of America that the school transport spread when Wayne Works built horse- drawn carriages - school hacks or kid hacks - in Indiana. Before having this means of transport, children went to school on foot, by wagon or sled. As car industry developed, Wayne Works took the opportunity to motorize these carriages, shortening travel time to schools. In 1936, the company developed a set of school buses and introduced the first design of school buses in steel. They are traditionally painted in yellow because this color is more visible in the morning and at night. Although the project was not very well accepted by parents, due to some safety issues, it was eventually considered one of the safest modes of school transport in the USA [9-11].

More recently, some cities have implemented school bus services, both on a permanent basis or as pilot initiatives. Some of the projects carried out mainly in Europe are mentioned below. At the Deutsche Schule, in London, the School Bus service has four routes. This service is available in the morning and afternoon. Costs associated with the service are incurred by the parents [12]. According to the newspaper The Guardian [13], some schools in London, Manchester and Edinburgh are taking steps to prohibit automobile traffic nearby schools. The Scottish government is committed to encouraging active transportation to and from school and reducing car dependence. In Scotland, during the "rush hour" - in the morning and in the afternoon- it is estimated that one in five cars on the road are busy transporting children to school. The government is interested in reducing the use of cars as a way to improve the health and well-being of children and 
young people, while reducing congestion and decreasing CO2 emissions. In 2009, the city of Lisbon carried out a mobility project aimed at implementing a bus system for public schools. This project aimed to reduce student mobility costs. The municipality traced some specific circuits (home-school and school-home), for students living more than 6 min' walk from school. Routes were established so that children would not have to walk long to get to the bus. The buses "Alfacinhas" had the capacity for 24 children, with average travel time of $15 \mathrm{~min}$. Each bus had someone who was responsible for picking up and delivering each child to their parents, at the previously designated 'bus stop' [14]. In Canada, the Red Deer Catholic Regional Schools have implemented the School Bus service. Service costs are incurred by the families. Regarded as an extension of the school facilities, students cannot eat, drink, or stand when inside the buses. This service includes a mobile application that allows parents to know if the school bus is delayed or if, for some reason, it has been cancelled [15]

In general, studies about school buses show that they can be an effective alternative to using the car, or to walking to school. Besides the positive effects in terms of families' spent time and money, air quality and urban traffic, there are also some advantages associated to the well-being of children, such as: (1) the strengthening of personal contact, thus favoring sociability, as children have the possibility of interacting with colleagues of different ages and conditions, fostering feelings of trust and self-esteem; (2) the development of children's autonomy; (3) the safety of children, as public transportation is safer than cars, and school buses have low accident rates, most of which do not imply lethal injuries [16-20]. The more children are on buses, the fewer cars are on the roads.

\section{The School Bus Project in Braga}

The School Bus Project in Braga aims at reducing traffic both in the city centre and in the main entrances of the city, especially during morning rush hour. It has been designed and implemented by the Municipality of Braga in a partnership with a wider project - Braga Urban Innovation Laboratory Demonstrator ${ }^{1}$ (BUILD). The project encompasses six schools: Colégio Leonardo Da Vinci, Colégio D. Diogo de Sousa, Colégio Teresiano, EB 2.3 Francisco Sanches, EB 2.3 André Soares and Conservatório de Música Calouste Gulbenkian. After the first experience in 2017, the school bus has been steadily operating since September 2018, with 413 children enrolled. Parents leave their children at one of the four interfaces (Municipal Stadium, Maximinos, Minho Center, Tenões) and they are, then, transported by bus to the schools' facilities. Being an important measure of the urban mobility policy, the Municipality undertakes all the costs of this program, so all families may benefit from free transportation, regardless of social and economic status (Fig. 3).

\footnotetext{
${ }^{1}$ Braga Urban Innovation Laboratory Demonstrator (BUILD) is a project of the Municipality of Braga with the following scientific partners: University of Minho, International Iberian Nanotechnology Laboratory and Centre for Computer Graphics; funded by the Fundo Ambiental Ministry of the Environment.
} 


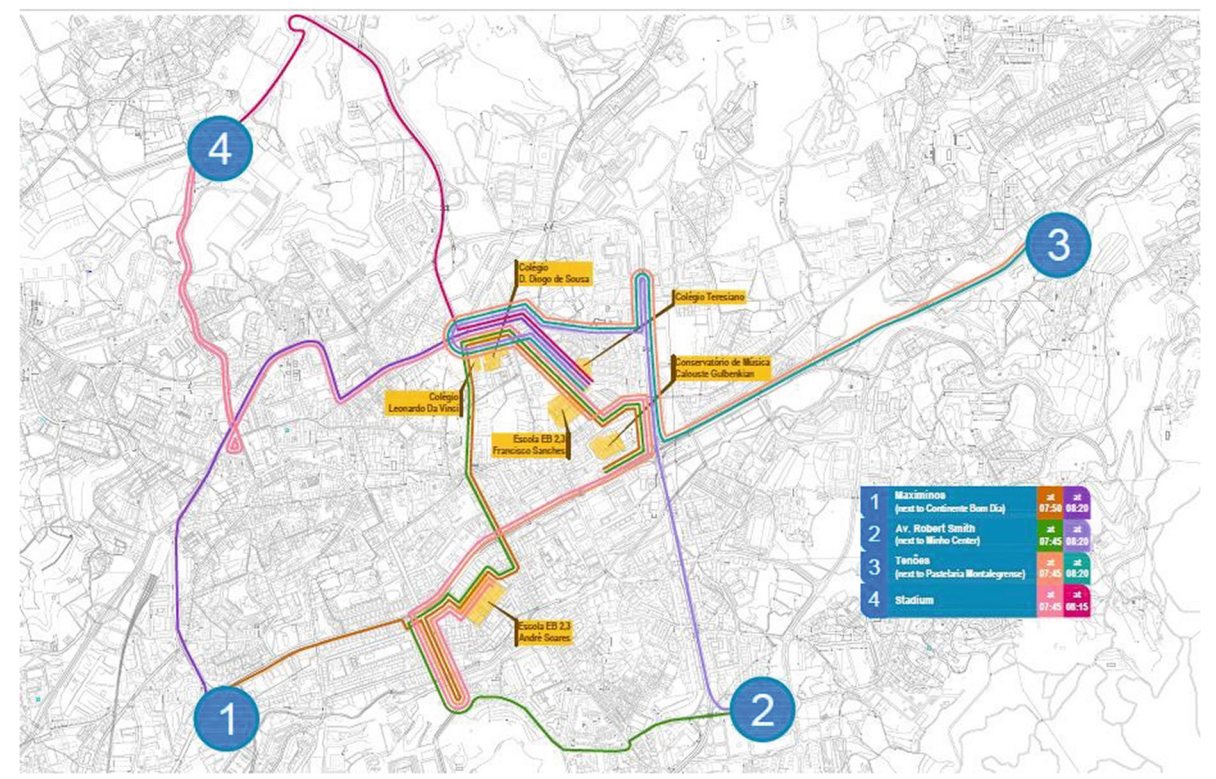

Fig. 3. School bus interfaces and routes in Braga Source: Municipality of Braga

\section{Methodological Note}

This paper is based on bibliographic research on the use and history of the school bus and the results of a study conducted in the city of Braga on the School Bus project. The methodological choices allowed us to assess the project, as well as to analyse families' mobility practices and major concerns presented by some important stakeholders around thinking and reframing school mobility. A mixed method was followed, using qualitative and quantitative research techniques. Methodology encompassed systematic observation, focus groups, interviews and a survey.

The interviews involved some important players including school principals, parents and representatives of other entities, such as the police, the parish and the county council. The semi structured interviews were done according to a guide integrating the agents' concerns, personal experience and the identification of measures they suggested to solve problems related to school mobility. The interviews were recorded. After the transcription they were analysed according to content analysis procedures using MaxQda software.

The focus groups were conducted with children. Part of them were school bus users, others were not. These sessions with the children lasted for a maximum of $90 \mathrm{~min}$. Children were asked to draw their main mean of transportation and then challenged to speak about it and share some ideas about the type of things they would change in their daily habits linked to mobility. Following data collection and systematization in a database, content analysis was used to extract information about three dimensions: the most frequent means of transportation to and from school, desire and intention of changing something in the trip. 
The survey was applied to parents of children registered to use the School Bus. The questionnaire consisted of 27 questions, about sociodemographic information, safety perception on the areas surrounding schools, school mobility practices and satisfaction with the use of School Bus. The questionnaires were handed out to children in order to be filled in by their parents.

96 (out of the 130 delivered surveys) responses were received, involving 127 children, which represents a high response rate, ensuring considerable reliability of the conclusions. SPSS software was used to analyse the data.

\section{Project Evaluation}

\subsection{School Directors}

Mostly, school directors highlight the fact that the project contributes to creating new mobility habits, because "children who use public transport now will also use it later in life" (director of Colégio Leonardo da Vinci). In the interviews, directors stressed three main positive achievements: (1) student's punctuality, as children who use the School Bus do not arrive late to school. According to the director of Colégio D. Diogo de Sousa, the initiative "disciplines and helps students stick to schedules"; (2) pedagogical advantage for participating children as they arrive to school more willing and motivated for pedagogical activities than children who come by car. Children who take the school bus "arrive in a happier mood, more motivated to take classes. Children who arrive late with their parents, after working through the rush hour, directly into the classroom do not have the same healthy disposition" (Director of Colégio Leonardo da Vinci); (3) a significant decrease of traffic in the area nearby school, making it a more pleasant place for users (security, air quality, and calmness). However, directors also mention some negative aspects, namely the fact that the School Bus is not available for children of all ages, families are not yet aware of its advantages and struggle with the change in behaviour regarding the use and parking of cars near schools.

\subsection{Parents}

Even if they evaluate the School Bus very positively ( $82 \%$ rate it as excellent or very good and $98 \%$ intend to continue using the service in the future), parents seem to have some mixed feelings concerning the need to leave the children at the bus stop or taking them by car. According to the data gathered in the parents' evaluation survey, these contradictions are due to subjective representations and evaluation about children's safety, as well as their instinct to protect kids and a wish to spend as much time as they can with them, even if in traffic jams. The evaluation survey results show that parents are highly satisfied with the project as they feel children are more "independent, autonomous, and safe", they meet (new) friends, "they like to go with their mates, it is comfortable and makes them feel free and they are able to arrive earlier to school", which is almost impossible when traveling by car. 
Parents also say that the School Bus helps them saving time in traffic as they are able to avoid the usual jams near schools and go directly to the workplace. Punctuality and quality of life are also mentioned. The table below sums up the most positive aspects mentioned by the parents (Table 1).

Table 1. Positive and negative aspects mentioned by parents in their evaluation of the school bus project in Braga

\begin{tabular}{l|l}
\hline Positive aspects & Negative aspects \\
\hline - Decrease in traffic and pollution & $\begin{array}{l}\text { - The school bus should also ensure the bus } \\
\text { ride home }\end{array}$ \\
\hline $\begin{array}{l}\text { - Strengthening of friendship ties with } \\
\text { neighbors, both for children and their } \\
\text { families }\end{array}$ & $\begin{array}{l}\text { - Schedules should be more adequate, so that } \\
\text { children should not have to get up so early } \\
\text { in the morning }\end{array}$ \\
\hline - Punctuality & $\begin{array}{l}\text { More routes and schedules should be } \\
\text { available, for more flexibility }\end{array}$ \\
\hline - Time saving for the family & \\
\hline
\end{tabular}

Overall, parents are very critical of the efficiency, availability and organization of public and school transportation in the city of Braga, not to mention the need for a service tailored to their daily routines. Besides, parents strongly claim that the spaces surrounding schools should be more secure and car-free, and users (especially parents) should avoid inappropriate behaviour such as parking in the middle of the street, or outside the parking spaces.

\subsection{Children}

Despite being very young (6 to 15), most of the School Bus users have strong opinions about this type of home-to-school transport. Because of their age, qualitative data gathering was an obvious choice. Focus groups took place in schools and sessions encompassed debating, writing and drawing about mobility. Participants were both School Bus users and non-users. Interestingly, $60 \%$ of the latter said they would like to join it. For those already using this service, positive opinions are over $95 \%$ and the main reasons for that are the urge to protect the environment, socializing with friends and arriving to classes on time (Fig. 4).

\section{Children's Right to the City: What Still Needs to be Done}

Somewhat unexpectedly, and contrary to the current environmental challenges and recent problems in urban areas, families seem to be increasingly dependent on cars. The pace of life, the need to respond to various demands located in different spaces, the distances between home and the workplace, the inefficiency of the public transportation network, the ever-increasing supply of cars are some of the reasons used to justify the increase in car users [21]. One of the factors that contribute greatly to the use of cars is also 


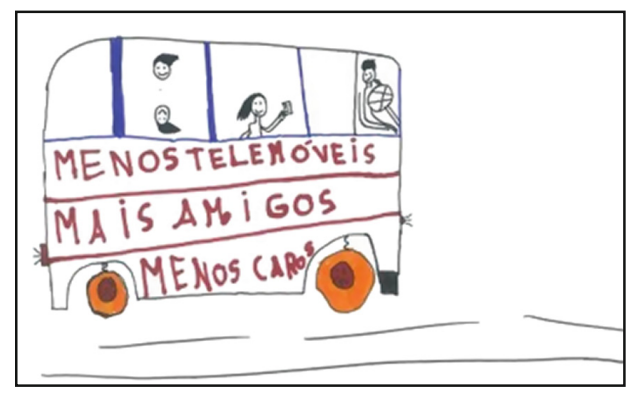

Fig. 4. Child's drawing depicting the school bus ("Less mobile phones, more friends, less cars")

the number of after school activities children are involved in every day, which implies traveling both from home and from school. These activities include sports, music classes, foreign languages classes, among others [21, 22].

The analysis of the existing literature and the qualitative research conducted in the context of the School Bus project in Braga shows that the transportation of children and young people is a major issue in "smart cities" agenda, not only because of decarbonisation and quality of life in city centres, but also because short daily home- school-work commuting is deeply connected to societal challenges such as territorial and social cohesion, citizenship and participation, and bottom-up strategies for urban ecosystems [23-25].

To this end, measures that bring children and young people to the centre of the analysis contribute to thinking about the public space from the perspective and experience of those who will shape the future of our cities [26, 27]. For this purpose, social research ought to focus on the appropriation of spaces and commuting patterns of different social groups. Additionally, attention should be drawn to the risks and dangers associated with urban

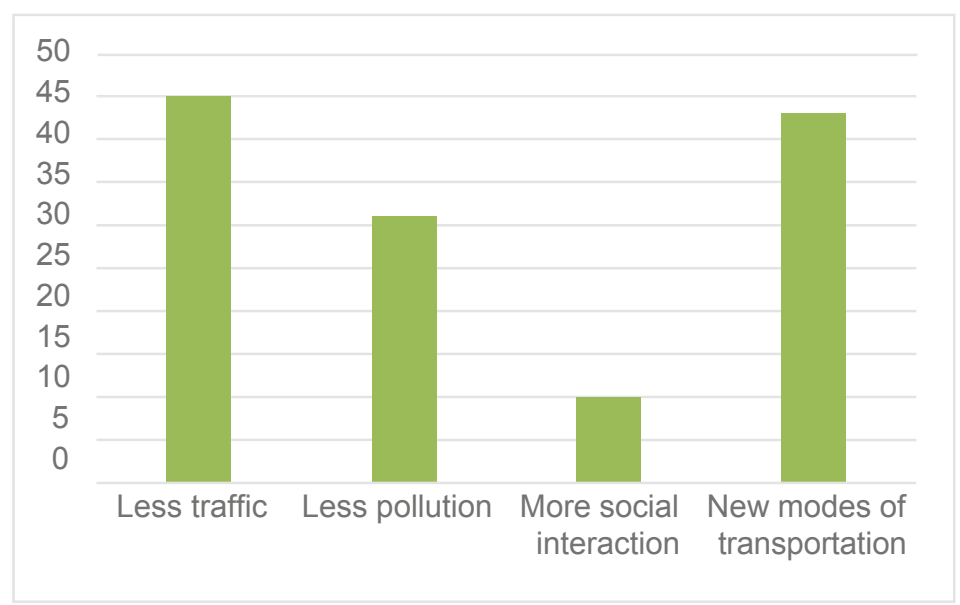

Fig. 5. Children's suggestions for change regarding mobility Source: Information provided by children's focus groups 
circulation, intervention measures that favour the participation of children in the design of the city (see Fig. 5) and the routes to be carried out daily.

\section{Concluding Remarks}

In this text, we intended to present the main advantages of using the school bus on the routes to school, considering the importance of including children's mobility as a priority in the planning and design of cities in the future.

Transporting children to schools is a matter of great relevance in the analysis of mobility patterns of families [28] and has a significant impact not only on families' daily lives, but also on the organization of the territory because home to school commuting represents a weighty part of traffic congestion in the cities, especially during rush hours, both in the morning and by the end of the day [29].

However, using the car has a number of consequences, including for the health and well-being of children. Some are visible (for example, public spaces overcrowded with cars and the insecurity it entails). Others are more implicit, such as hindrances to children's autonomy or lack of physical activity.

Given the School Bus project's results, we may conclude that the objectives have been partially achieved, by having demonstrated the relevance of children and families' support for social and environmental sustainability regarding circulation in urban areas.

Funding. Funded by FCT - Fundação para a Ciência e Tecnologia, within the UID/CCI/ 00736/2019 project scope. Funded by Fundo Ambiental, project BUILD-Braga Urban Innovation Laboratory Demonstrator.

\section{References}

1. Banister, D.: The sustainable mobility paradigma. Transp. Policy 15, 73-80 (2008)

2. Meaton, J., Kingham, S.: Children's perceptions of transport modes: car culture in the classroom? World Transp. Policy Pract. 4(2), 12-16 (1998)

3. O'Brien C.: Children: a critical link for changing driving behaviour. York Centre for applied sustainability. York University, Toronto, Canada (2000). http://www.bikewalk.org/pdfs/child rendrivingbehavior.pdf. Accessed 21 June 2019

4. Mackett, R.: Increasing car dependency of children: should we be worried? Munic. Eng. 151(1), 29-38 (2002)

5. Teles, P. (coord.): Estudo de mobilidade e gestão de tráfego. Câmara Municipal de Braga (2018)

6. INE - Instituto Nacional de Estatística: Inquérito à Mobilidade nas Áreas Metropolitanas do Porto e de Lisboa (2018). https://www.ine.pt/xportal/xmain?xpid=INE\&xpgid=ine_p ublicacoes\&PUBLICACOESpub_boui=349495406\&PUBLICACOESmodo=2\&\&fbclid $=$ IwAR2QzUZK0mUSEdKySZe1HqmObblKWR62vIyVhtVAAxrQhyNllna-DDfp2bk\&xlan $\mathrm{g}=\mathrm{pt}$. Accessed 25 June 2019

7. INE - Instituto Nacional de Estatística, Meio de transporte mais utilizado nos movimentos pendulares (2001). https://www.ine.pt/xportal/xmain?xpid=INE\&xpgid=ine_indicadores\&i ndOcorrCod $=0000684 \&$ contexto $=$ bd $\&$ selTab $=$ tab2 . Accessed 25 June 2019 
8. INE - Instituto Nacional de Estatística, Meio de transporte mais utilizado nos movimentos pendulares (2011). https://www.ine.pt/xportal/xmain?xpid=INE\&xpgid=ine_indicadores\&i ndOcorrCod=0007093\&contexto=bd\&selTab $=$ tab2. Accessed 25 June 2019

9. The Newswhell. History of the School Bus. (Blog post). https://thenewswheel.com/history-o f-the-school-bus/. Accessed 11 June 2019

10. Transportation and Scholl Busing. The School Bus, History of Pupil Transportation, Issues in Pupil Transportation: https://education.stateuniversity.com/pages/2512/Transportation-Sc hool-Busing.html. Accessed 11 June 2019

11. Wagons, Hacks, and Sledges: History of the School Bus. https://www.edgarsnyder.com/blo g/2015/08/history-of-school-bus.html. Accessed 11 June 2019

12. Deutsche Shule London, School Bus. https://www.dslondon.org.uk/admissions/school-bus. Accessed 08 June 2019

13. The Guardian, UK schools banning school run to protect pupils from air pollution. https://w ww.theguardian.com/environment/2018/jul/13/uk-schools-move-to-ban-the-school-run-toprotect-pupils-from-air-pollution. Accessed 08 June 2019

14. Martíneza, L., Viegasa, J.: Design and deployment of an innovative school bus service in Lisboa. Procedia Soc. Behav. Sci. 20, 120-130 (2011)

15. Red Deer Catholic Regional Schools, School Bus Information. https://www.rdcrs.ca/schools /school-bus-information. Accessed 08 June 2019

16. Tamanaha, S.: Design para sistema de transporte de estudantes. Dissertação de final de curso, Universidade de São Paulo, Brasil (2014). http://www.fau.usp.br/fauforma/2015/assets/sergi o_tamanaha.pdf. Accessed 18 May 2019

17. Yang, J., Peek-Asa, C., Cheng, G., Heiden, E., Falb, S., Ramirez, M.: Incidence and characteristics of school bus crashes and injuries. Accid. Anal. Prev. 41, 336-341 (2009)

18. Desai, M., Takkalaki, P., Bhapri, M., Marshanalli, A., Malage, G.: Students tracking system for school bus. Int. Res. J. Eng. Technol. 4(6), 2554-2557 (2017)

19. Kotoulaa, K., Botzoris, G., Morfoulaki, M., Aifandopoulou, G.: The existing school transportation framework in Greece - barriers and problems comparing to other European countries. Transp. Res. 24, 385-392 (2017)

20. Tenniz, Z., Yilmaz, S.: Attention! school bus. Eur. J. Educ. Stud. 4(2), 276-288 (2018)

21. Dowling, R.: Cultures of mothering and car use in suburban Sydney: a preliminary investigation. Geoforum 31, 345-353 (2000)

22. Hjorthol, R., Fyhri, A.: Do organized leisure activities for children encourage car-use? Transp. Res. 43, 209-218 (2009)

23. Moodie, M., Haby, M., Galvin, L., Swinburn, B., Carter, R.: Cost-effectiveness of active transport for primary school children - walking school bus program. Int. J. Behav. Nutr. Phys. Act. 6, 1-11 (2009). https://doi.org/10.1186/1479-5868-6-63

24. Nasrudin, N., Nor, A.: Travelling to school: transportation selection by parents and awareness towards sustainable transportation. Procedia Environ. Sci. 17, 392-400 (2013)

25. Lopes, F., Cordovil, R., Neto, C.: Children's independent mobility in Portugal: effects of urbanization degree and motorized modes of travel. J. Transp. Geogr. 41, 210-219 (2014)

26. Pojani, D., Stead, D.: Sustainable urban transport in the developing world: beyond megacities. Sustainability 7, 7784-7805 (2015)

27. Baslington, H.: Travel socialization: a social theory of travel mode behavior. Int. J. Sustain. Transp. 2, 91-114 (2008)

28. Oliveira, C.S., Cruz, M.: Urban mobility patterns and the use of public transports in Portugal. In: Proceedings Clima 2008. Universidade de Aveiro (2008)

29. Ristell, J., Enoch, M., Quddus, M., Hardy, P.: Expert perspectives on the role of the bus in school travel. Munic. Eng. 166(1), 53-58 (2013) 